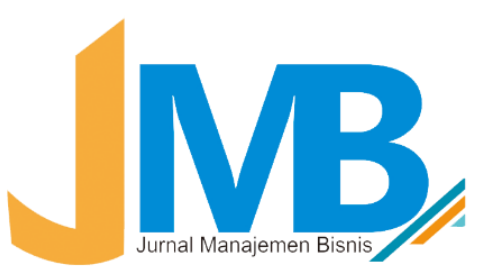

\title{
ANALYSIS OF INVESTOR BEHAVIOR IN THE ISLAMIC CAPITAL MARKET WITH AN APPROACH TRA (THEORY OF REASONED ACTION)
}

\author{
Istu Putri Swasti ${ }^{1}$, Sumadi ${ }^{2}$ \\ Indonesia Islamic University, \\ Coresponding Email : istuputris@gmail.com,Yogyakarta
}

Received:11-05-2020 / Revision: 11-09-2020 / Accepted:11-09-2020

To cite this document:

Swasti, Istu Putri, (2020) “ Analysis of Investor Behavior in the Islamic Capital Market

with an Approach TRA (Theory of Reasoned Action)", ManajemenBisnis, Vol. 10, No. 1, pp.58-66, http://ejournal.umm.ac.id/index.php/jmb/issue/view/10741

\begin{abstract}
The development of the capital market in Indonesia is very significant, with the implementation of the Yuk Savings Stock campaign to increase the number of domestic investors in Indonesia. The Indonesian Central Securities Depository (KSEI) noted that as of August 9, 2019, the number of capital market investors reached 2,070,394 people, an increase of 27.8 percent from the position in December 2018. This study aimed to find out and analyze Investment Knowledge on Attitudes, Investment Motivation on Attitudes, Perceptions of Risks towards Attitudes, Attitudes Influence Interests, Subjective Norms Affect Investment Interests, and Investment Interests Affect Investors Behavior in Sharia Capital Market. The population in this study are Islamic Capital Market investors in the DIY \& Central Java region. Samples taken in this study are some Shariah Investors in DIY \& Central Java, which total 213 respondents. Sampling using non-probability techniques with convenience sampling method and research models will be analyzed using Structural Equation Model (SEM). The results of this study indicate that investment knowledge has a significant negative effect on attitude, investment motivation has a significant positive effect on attitude, perception of risk has a significant negative effect on attitude, attitude has a significant positive effect on interest, subjective norms has a significant positive effect on interest and interest has a significant positive effect on investor behavior.
\end{abstract}

Keywords: Investment Knowledge, Investment Motivation, Risk Perception, Investment INTRODUCTION Attitude, Subjective Norms, Intention, Investor Behavior

Citing the official page of the Indonesia Stock Exchange, the stock exchange has been presented by the Dutch East Indies in Batavia since 1912 for the benefit of the Vereenigde Oostindische Compagnie (VOC). World War I and II, had made the capital market inactive, until finally vacuum in the period 1956-1977. Then on August 10, 1977 President Soeharto reactivated the capital market in Jakarta. Capital Market Implementing Agency (Bapepam). Then in 1995 the Republic of Indonesia Law No. 8 
of 1995 concerning the Capital Market was published. The development of the capital market in Indonesia is very significant, with the implementation of the "Yuk Nabung Saham" campaign to increase the number of domestic investors in Indonesia. This is proven by the Indonesian Central Securities Depository (KSEI) recorded as of August 9, 2019 , the number of capital market investors reached 2,070,394 people, an increase of 27.8 percent from the December 2018 position of 1,619,372 people.

Based on the book Islamic Capital Market by Irwan Abdalloh (2018) In general, what is meant by the Islamic capital market is all activities in the capital market that comply with Islamic principles. The sharia investment product in the form of mutual funds is the first sharia product in the world that was launched to accommodate excess funds. Just like in Indonesia, the first sharia securities launched were investment products in the form of sharia mutual funds in 1997. Theory Reasoned Action (TRA) is a research model that explains that actual behavior is actual actions or activities, carried out because individuals have an intention or desire to do so (Ajzen \& Fishbein, 1975). Thus, a person's interests or desires can influence people to carry out certain activities or actions. Previous research has been investigated by Alleyne \& Br (2010) which states intention has a positive effect on behavior.

In Theory Reasoned Action (TRA) variables that influence intention are Attitudes and Subjective Norms. The attitude of behavior is a positive or negative feeling from someone should carry out the behavior to be determined (Davis, 1989). According to research by Phan \& Zhou (2014) Attitude has a positive and significant influence on investment interests in the capital market. According to Ajzen (2005), subjective norms are one's perception of social pressure to do or not do. Previous research states that subjective norms have a significant positive effect on interest (Abul, 2019). However, different research states that subjective norms do not affect interest (Idris \& Kasmo, 2017). There are several factors behind attitudes, namely Knowledge, Motivation, and Perception of Risk. According to Efferin \& Sujoko (2008) knowledge is the basis for the formation of a power for someone to be able to do something they want. But many investors believe that they have more knowledge than other investors (Shiller, 2015). A study by Riaz \& Iqbal (2015) found that over-confidence because having knowledge has a significant impact on investment decisions regarding on the Karachi Stock Exchange.

According to Robbins (2006) motivation is a process of assistance that can determine the motivation, direction, and perseverance of individuals in an effort to achieve goals and facilitate directly on one's tasks and psychology. Motivation is related to the level of investor optimism. Upbeat investors are confident that the market will perform well and prices will continue to rise. Motivational research on attitudes published by Solesvik (2013) which states positive and significant motivations for attitudes. Excessive optimism also has a positive impact on investment attitudes and encourages people to invest (Garvis, et al, 2002). According to Sharpe (2005) returns and risk levels cannot be returned from investments in the capital market because the higher the return on investment, the higher the risk will also be higher. Published research on the influence of trends on attitudes that have been examined by (Abul, 2019) which states that the perception of risk defines a significant negative. With the results of research that have yet to produce and many people who have not yet invested in the Capital Market, researchers are motivated to conduct research under the title "Analysts of Investor behavior in the Islamic Capital Market by seeking TRA (Reasonable Action Theory)". 


\section{LITERATURE REVIEW}

Theory of Reason Action (TRA) was created by Ajzen and Fishbein in 1975, this theory explains that a person is determined by an intention which is a function of the behavior of the subjective norm mode. This intention can predict someone very well and represent a cognitive representation of one's readiness for behavior.

TRA is influenced by intention, while intention is influenced by attitudes and subjective norms. The attitude is influenced by confidence in the results of past actions. Subjective norms are influenced by beliefs in the opinions of others and motivation to obey those opinions. Islamic Capital Market, according to Law Number 8 of 1995 concerning Capital Market. Capital Market is an activity concerned with public offering and trading of securities of public companies relating to the issuance of securities, as well as institutions and professions related to securities. Based on this definition, the terminology of the Islamic capital market can be interpreted as all activities in the capital market that meet Islamic principles (Abdalloh, 2018).

Investment Knowledge, knowledge is the basis for forming a power for someone to be able to do something he wants (Efferin Sujoko, 2008). Knowledge will make it easier for someone to make investment decisions, Sufficient knowledge is needed to avoid losses when investing in the capital market.Motivation is the process of giving encouragement that can determine the intensity, direction, and perseverance of individuals in an effort to achieve goals and directly affect the task and psychology of a person (Robbins, 2006). Risk Perception, perceived risk is a previous measure of perceived benefits and perceived ease of use prior to making an investment. Investment in the capital market cannot be separated between return and risk level because the higher the return to be obtained (high risk return) in investment, the risk faced will also be higher (Sharpe, 2005). Investment Attitude, attitude is a predisposition that is learned in responding permanently to an object, in the form of liking or disliking (Schiffman \& Kanuk, 2010)

Subjective Norms, subjective Norms are interpreted as a person's opinion about whether an important person for that person is empowered with behavioral efforts that should be implemented (Ajzen, 2005). Intention, intention is a tendency that remains in the subject to feel happy and interested in a certain field or thing and feel happy to be involved in that field (Winkel, 1983), Investor Behavior, theory Reasoned Action (TRA) explains that the actual behavior (actual behavior) is an actual action or activity, carried out because the individual has an intention or desire to do so. So that someone's interest or desire can influence someone to carry out certain activities or actions.

\section{Effect of Investment Knowledge on Attitude}

According to Efferin \& Sujoko (2008) Knowledge is the basis for the formation of a power for someone to be able to do what he wants. But many investors are too confident that they have more knowledge than other investors (Shiller, 2015). Therefore, overconfidence about one's ability directly influences the attitude of investing. Previous research on the effect of education on attitudes has been investigated by Alfrita, (2019) states that knowledge affects Investment Intention. states that knowledge affects Investment Intention

Such results are already with research Hidayat, Muktiadji, \& Supriadi, (2019). 
H1: Investment Knowledge has a significant negative effect on investment attitudes in the Islamic capital market.

Effect of Motivation on Attitudes

According to Robbins (2006) Motivation is the process of giving encouragement that can determine the intensity, direction, and perseverance of an individual in an effort to achieve goals and have a direct effect on one's tasks and psychology. Motivation is related to the level of investor optimism. Upbeat investors are confident that the market will perform well. Excessive optimism also has a positive impact on investment attitudes and encourages people to invest (Garvais, et al, 2002) Research on the influence of motivation on attitudes has been investigated by Solesvik (2013) which states that motivation has a positive and significant effect on attitudes. H2: Motivation has a significant positive effect on investment attitudes in the Islamic capital market.

Influence of Perception on Risk with Attitude

According to Sharpe (2005) Investment in the capital market cannot be separated between return and risk level because the higher the return to be obtained in investment, the risk faced will also be higher. Risk is the possibility of the difference between the actual return and the expected return. (Eduardus, 2001). Previous research examining the effect of perceptions of risk on attitudes was examined by Phan \& Zhou (2014) which stated that the perception of risk had a significant negative effect. H3: Perception of risk has a significant negative effect on attitude in the Islamic capital market.

Effect of Attitude on Investment Interest

The attitude of behavior is a positive or negative feeling from someone who is supposed to carry out the behavior to be determined (Davis, 1989). If someone has a better attitude toward a certain behavior, the chances are higher that they will have an interest in carrying out that behavior (Ajzen and Fishbein 1980).

According to research by Phan \& Zhou (2014) Attitude has a positive and significant influence on investment interests in the capital market. H4: Attitude has a significant positive effect on interest in investing in the Islamic capital market

Effect of Subjective Norms on Investment Interest

According to Ajzen (2005), subjective norms are one's perception of social pressure to do or not do. It is believed that if important people do not agree with the behavior, the chances are higher that they will not have an interest. This means, even if someone does not like the behavior, he can still do it under pressure and social influence (Venkatesh and Davis 2000). Previous research states that subjective norms have a significant positive effect on interest (Abul, 2019). H5: Subjective Norms have a significant positive effect on investment interests in the Islamic capital market Influence of Interest on Investment Behavior

According to Kotler \& Keller (2016) interest is something that arises after receiving a stimulus. Basically, interests and actual behavior are two different things. Interest is the desire of someone to conduct behavior. But this interest is only in the form of desire, not yet reflected in actions or behavior. While the actual behavior is the actual action or activity carried out. According to Alleyne \& Br, (2010) Interest has a 
positive effect on behavior. H6: Interest has a significant positive effect on investor behavior in the Islamic capital market.

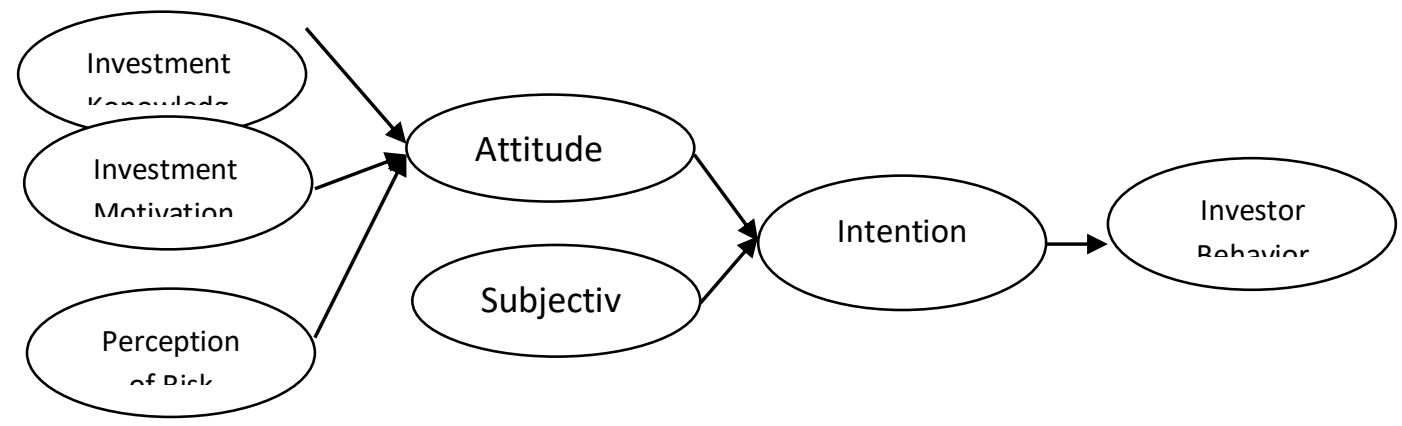

Figure 1. Research Framework

\section{RESEARCH METHOD}

The research conducted is a quantitative primary. In this study the population is the Islamic Capital Market investors in the region of DIY \& Central Java. The sample selection in this study was carried out using the purposive sampling method. The number of samples in this study were 213 respondents. With the data testing process using SEM AMOS 20.

\section{RESULT AND DISCUSSION}

Tabel 1. Hypothesis Test Results

\begin{tabular}{|l|c|l|l|l|l|}
\hline $\begin{array}{l}\text { Relations Between } \\
\text { Variables }\end{array}$ & Standardized & S.E. & C.R. & P & Information \\
\hline SK<--PI &,- 113 &, 086 & $-2,163$ &, 005 & Accepted \\
\hline SK<--MO &, 998 &, 061 & 14,536 &, 000 & Accepted \\
\hline SK<--PR &,- 153 &, 039 & $-1,980$ &, 043 & Accepted \\
\hline MT<--SK &, 485 &, 061 & 14,536 &, 000 & Accepted \\
\hline MT<--NS &, 368 &, 116 & 4,542 &, 000 & Accepted \\
\hline PV<--MT &, 869 &, 061 & 14,536 &, 000 & Accepted \\
\hline
\end{tabular}

Source: Data processed from 2019

Information :

$\mathrm{p}$ value $<0.05$ or Critical Ratio value $>1.96$, then the hypothesis is accepted.

$\mathrm{p}$ value $>0.05$ or Critical Ratio value $<1.96$, the hypothesis is rejected.

Effect of Investment Knowledge on Attitude

The results of this study prove that Investment Knowledge has a negative and significant effect on investment attitudes. This means that if the investor's investment knowledge increases, it will decrease one's attitude to invest. According to Efferin \& Sujoko (2008) Knowledge is the basis for forming a power for someone to be able to do something they want. But many investors believe that they have more knowledge than other investors (Shiller, 2015). One typical aspect of overconfidence is the effect that considers better than average, where people believe their skills are better than average and think unrealistically about themselves (Taylor \& Brown, 1988). This result is not in 
accordance with Solesvik's (2013) study which states that students who participate in corporate education programs have a significantly high level of entrepreneurial motivation that promotes attitudes towards the company, so knowledge has a significant positive effect on attitudes. However, Odean's research (1998) argues that knowledgeable investors will tend to feel too confident that they believe they are smarter than other investors in terms of choosing the best time to buy shares at the best price, so that it has a significant negative effect on attitude. A study by Riaz \& Iqbal (2015) found that overconfidence because having knowledge had a significant negative impact on investment decisions regarding on the Karachi Stock Exchange. This research was supported by (Phan \& Zhou, 2014; Abul, 2019).

\section{Effect of Investment Motivation on Attitudes}

The results of this study prove that investment motivation has a positive and significant effect on attitude. The higher the Investment Motivation will increase the Attitude. According to Robbins (2006) Motivation is the process of giving encouragement that can determine the intensity, direction, and perseverance of an individual in an effort to achieve goals and have a direct effect on one's tasks and psychology. Motivation is related to the level of investor optimism. Upbeat investors are confident that the market will perform well and prices will continue to rise. Especially if this optimism is based on solid information about the company and supported by good economic indicators, it will have a positive impact on the market.

These results are consistent with Solesvik (2013) which states that motivation has a positive and significant effect on attitudes. A similar study was examined by Phan \& Zhou (2014); Abul (2019) who stated that optimism influences attitude.

\section{Influence of Perception on Risk to Attitude}

The results of this study prove that risk perception has a negative and significant effect on attitude. The higher the perception of risk will decrease attitude. Prospect theory by Tversky and Kahneman claims that people tend to resist risk (Kahneman \& Tversky, 1992). According to Lansing \& LeRoy (2014) investigated risk-loving investors but only a few investors behaved as risk lovers when they faced the need for cash. So it can be concluded that if an investment contains a large risk, investors will likely avoid it. This result is in line with Phan \& Zhou's research (2014) which states that risk perception has a significant negative effect on attitude. Different studies suggest that risk perception has a significant negative effect on attitude (Abul, 2019).

\section{The Effect of Attitudes Towards Investment Interest in Islamic Capital Markets}

The results of this study prove that attitude has a positive and significant effect on investment interests in the Islamic Capital Market. The higher attitude will increase investment interest in the Syariah Capital Market. Attitudes are defined as evaluative effects of positive or negative feelings of individuals in performing certain behaviors (Fishbein and Ajzen 1980). Interest in behavior itself is a function of the attitude of individual behavior. If it is associated with an interest in investing, a person's attitude will increase investment interest. The better the attitude value, the better the investment interest will be. If the consumer has decided the alternative to be chosen, then the consumer will carry out what is of interest. These results are in accordance with Phan \& Zhou's (2014) attitude. Positive and significant influence on investment interests in the capital market. The research is strengthened by research conducted by (Abul, 2019; 
Alleyne \& Br, 2010) which states that attitude has a positive effect on interest.

Effect of Subjective Norms on Investment Interest in Islamic Capital Markets

The results of this study prove that subjective norms have a positive and significant effect on investment interests in the Islamic Capital Market. The higher subjective norms will increase investment interest in the Islamic Capital Market. Subjective norms are one of two original constructs of TRA. According to Ajzen (2005), subjective norms are one's perception of social pressure to do or not do. Contribution of opinion from each reference given in the spirit of motivation, an individual should obey the expectations of the reference (Schiffman and Kanuk, 2010). Referents are groups around consumers when consumers identify themselves with that group, so consumers take a lot of values, attitudes, or behaviors of members in the group. When a customer considers important referral from a group, it will increase their intention to invest. This result is in line with previous research on subjective norms that has a significant positive effect on interest (Abul, 2019). This is supported by research by Alleyne \& Br (2010), Phan \& Zhou (2014) which states that Subjective Norms have a positive effect on interest.

Effect of Investment Interest on Investor Behavior in the Islamic Capital Market

The results of this study prove that interest has a positive and significant effect on Islamic Capital Market Investor Behavior. The higher interest will increase Sharia Capital Market Investor Behavior. Interests and Actual behavior are two different things. According to Kotler \& Keller (2016) interest is something that arises after receiving a stimulus. Thus, intentions show the element of enthusiasm that influences behavior and how individuals try to engage in behavior (Mafé, Blas, \& Tavera-Mesías, 2010) and build individual decisions according to whether individuals will carry out a behavior or not behave (Alasmari, 2018). These results are consistent with research by Alleyne \& Br, (2010) which states that interest has a positive effect on behavior. Research by Aghani (2019) also states that interest has a significant effect on behavior

\section{CONCLUSION}

After the researcher conducts the analysis and discussion several conclusions can be drawn: investment knowledge has a significant negative effect on attitude, investment knowledge a person will reduce the attitude of investing in the Capital Market. Investment motivation has a significant positive effect on attitude, which means that the higher the investment motivation will increase the attitude of investing in the Capital Market. Perceptions of risk have a significant negative effect on attitude, which means that the higher the perception of risk will reduce the attitude of investment in the capital market. Attitude has significant positive effect on Investment Interest, which means the higher attitude will increase Investment Interest in the Capital Market. Subjective norms have a significant positive effect on investment interests, which means that the higher the subjective norms will increase investment interest in the capital market. Investment Interest has a significant positive effect on the behavior of Investors, which means that the height of investment interest will increase investor behavior in the capital market. 


\section{REFERENCES}

Abdalloh, I. (2018). Pasar Modal Syariah. Jakarta: PT Elex Media Komputindo.

Abul, S. J. (2019). Factors influencing Individual Investor Behaviour: Evidence from the. Asian Social Science, 15 (3).

Aghani, W. H. (2019). Perilaku Konsumen terhadap E-Money. Tesis.

Ajzen, I. (2005). Attitudes, Personality and Behavior. New York USA: Open University Press.

Ajzen, I. (1991). The theory of planned behavior." Organizational Behavior and Human Decision Processes. 50 (2), 179-211.

Ajzen, I., \& Fishbein, M. (1975). Belief, Attitude, Intention, and Behavior: An Introduction to Theory and Research. Addison-Wesley, Reading, MA.

Alfrita, E. E. (2019). Pengaruh Pengetahuan Investasi terhadap Minat Berinvestasi Mahasiswa Jurusan Ekonomi Syariah Universitas Islam Negeri Sultan Syarif Kasim Riau.

Alleyne, P., \& Br, T. (2010). An exploratory study of factors influencing investment decisions of potential investors. Department of Management Studies, University of the West Indies. Central Bank of Barbados.

Davis, F. D. (1989). "Perceived Usefulness, Perceived Ease of Use, and User Acceptance of Information Technology" (Vols. MIS Quarterly.Vol. 13 No. 5: pp319-339.).

Eduardus, T. (2001). Analisis Investasi dan Manajemen Portofolio (Pertama ed.). Yogyakarta: BPFE-Yogyakarta.

Efferin, \& Sujoko. (2008). Metode Penelitian Akuntansi: Mengungkap Fenomena dengan pendekatan Kuantitatif dan Kualitatif. Yogyakarta: Graha Ilmu.

Hidayat, L., Muktiadji, N., \& Supriadi, Y. (2019). Pengaruh Pengetahuan Investasi Terhadap Minat Mahasiswa Berinvestasi di Galeri Investasi Perguruan Tinggi. Jurnal Analisis Sistem Pendidikan Tinggi , 3 (2), 63-70.

Idris, \& Kasmo, A. B. (2017). Pengaruh Sikap, Norma Subjektif dan Persepsi Kontrol Perilaku terhadap Minat Kepemilikan Kartu Kredit. Jurnal Manajemen Bisnis Indonesia , 4 (3).

Kahneman, D., \& Tversky, A. (1992). Advances in prospect theory: cumulative representation of uncertainty. Journal of Risk and Uncertainty , 5 (4), 297-323.

Kotler, P., \& Keller, K. L. (2016). Marketing Management -15/E. Essex. England: Pearson Education.

Lansing, K. J., \& LeRoy, S. F. (2014). Risk Aversion, Investor Information, and Stock Market Volatility. Federal Reserve Bank of San Francisco, Working Paper .

Odean, T. (1998). Are investors reluctant to realize their losses? The Journal of Finance, 53 (5), 1775-1798.

Phan, K. C., \& Zhou, J. (2014). Factors Influencing Individual Investor Behavior: An Empirical Study of the Vietnamese Stock Market. American Journal of Business and Management , 3, 77-94.

Riaz, I., \& Iqbal, H. (2015). Impact of Overconfidence, Illusion of control, Self-Control and Optimism Bias on Investors Decision Making; Evidence from Developing Markets. Research Journal of Finance and Accounting , 6 (11), 110-115.

Robbins, S. (2006). Peningkatan Kinerja Melalui Perilaku Kerja Berdasarkan Kecerdasan Emosional. Perilaku Organisasi , 7.

Schiffman, L. G., \& Leslie, L. K. (2010). Consumer Behavior Tenth Edition. Pearson Education. 
Sharpe, W. F. (2005). Investasi (terjemahan). Jakarta: Indeks.

Shiller, R. J. (2015). Irrational Exuberance: Revised and Expanded (3rd ed.). Princeton: Princeton University.

Solesvik, M. Z. (2013). Entrepreneurial motivations and intentions: investigating the role of education major. Education p Training , 55 (3), 253-271.

Taylor, S. E., \& Brown, J. D. (1988). Illusion and well-being: A social psychological perspective on mental health. Psychological Bulletin , 103 (2), pp. 193-210.

Winkel, W. S. (1983). Psikologi Pengajaran. Jakarta: Gramedia Widia Sarana Indonesia. 